(RESEARCH ARTICLE)

\title{
Effect of season and different dietary protein level on production and reproductive performance and egg characteristics of indigenous Guinea fowl (Numida meleagris) in the middle belt of Ghana
}

Korankye Okyere ${ }^{1,}{ }^{*}$, James Kwame Kagya-Agyemang ${ }^{1}$, Annor Serekye Yaw ${ }^{1}$, Akwasi Asabere-Ameyaw ${ }^{2}$, and Clement Gyeabour Kyere 1,*

${ }^{1}$ Department of Animal Science Education, Faculty of Agriculture Education, University of Education, Winneba, Post Office Box 40, Mampong-Ashanti, Ghana.

${ }^{2}$ Department of Biology Education, Faculty of Science Education, University of Education of Winneba, P.O. Box 25,

Winneba, Ghana.

Publication history: Received on 13 December 2020; revised on 20 December 2020; accepted on 22 December 2020

Article DOI: https://doi.org/10.30574/wjarr.2020.8.3.0486

\begin{abstract}
This study was undertaken to determine the impact of seasonal variations and different dietary protein levels on production traits, reproductive performance and egg characteristics of Guinea fowl (Numida meleagris) in the Middle belt of Ghana. Twelve (12) males and forty-eight (48) females Pearl Guinea fowls of 12 weeks of age were subjected to isocaloric diet containing 16\%, 18\%, 20\% and $22 \%$ crude protein levels.Each group was replicated three times and reared in three seasons (Dry-December-March, Major rains-April-July and Minor rains-August-November) in a 3x4 factorial experiment. Data were analyzed using General Linear Model procedure of SAS.Hen day egg production (HDEP) and egg mass increased $(\mathrm{p}<0.05)$, but feed intake, feed conversion ratio, egg weight, fertility and hatchability of incubated eggs were not significantly different $(p>0.05)$ with increasing dietary protein. Egg quality traits did not differ significantly $(p>0.05)$ except egg yolk $(p<0.05)$. Season showed positive $(p<0.05)$ relationship with all production traits as well as fertility of incubated eggs, but not hatchability ( $p>0.05)$. Egg internal and external traits were significantly $(p<0.05)$ influenced by season except yolk weight and shell weight $(p>0.05)$.Results demonstrates that increasing dietary protein promoted egg production and reproductive traits in Guinea fowl, nevertheless, $16 \%$ crude protein diet is sufficient to support optimum egg production, fertility and hatchability, and egg characteristics. Rainy seasons countenance production traits, fertility and hatchability as well as egg characteristics, thus, breeding should be planned to take advantage of the major rainy season.
\end{abstract}

Keywords: Season; Dietary protein; Production characteristics; Reproductive traits; Egg characteristics

\section{Introduction}

The estimated per capita consumption of poultry products in Ghana increased by 33 percent from $4 \mathrm{~kg}$ meat in 2010 to $6.6 \mathrm{~kg}$ in 2012. It has been projected that the per capita consumption may increase to $6.8 \mathrm{~kg}$ in 2013 [1]. Guinea fowls, in recent times, have assumed significant importance in the commercialization of poultry in the world. Today, the bird is raised in commercial quantities in other part of the world, especially in Asia, other than West African countries where the bird originates. The study of Adeyemo et al. [2] showed that there is greater market potential for Guinea fowl products in many African countries.

Earlier writers indicated thatmajor constrain to the commercialization of Guinea fowl was its production and reproductive response to season [3]. In Northern part of Ghana, Guinea fowl production and reproductive performance peak in the wet season. It has further been indicated that Guinea fowl performance depends on access to quality

${ }^{*}$ Corresponding author: Clement Gyeabour Kyere Email: kyere.clement@yahoo.com 
nutrition which is not available at all seasons [4]. Recent production of the bird has been grounded on commercially prepared feed which has been adopted as producers gear towards intensive system of rearing and also to supplement the feeding of the bird in the semi-intensive system. Studies have demonstrated that Guinea fowl protein requirement for optimum egg production is $16 \%$ [5], but the requirement for optimum reproductive performance has not been studied extensively.

The present investigation was undertaken to study the dietary protein requirement of layer Guinea fowl for optimum egg production, reproductive performance and egg characteristics.

\section{Material and methods}

\subsection{Study location and duration}

The study was conducted at the Poultry Unit of the Department of Animal Science Education, University of Education, Winneba, Mampong campus from September, 2016 to December, 2017. Asante Mampong is the capital town of the Mampong Municipality of the Ashanti Region. Mampong is located $60 \mathrm{~km}$ North-East of Kumasi on the Kumasi- Ejura road. The Municipality lies between latitude 07 040" degrees North and longitude 0124 " degrees west with altitude $457.1 \mathrm{~m}$ above sea level in the Transitional Zone between the Guinea Savanna Zone of the north and Tropical Rain Forest of the south of Ghana. The climatic condition is wet semi-equatorial type, with a bi-modal rainfall of $1224 \mathrm{~mm}$ per annum and temperature range of $22.3^{\circ} \mathrm{C}-30.6^{\circ} \mathrm{C}$. Rainfall occurs in April to July (Major Raining Season), August to November (Minor Rainy Season) and December to March (Dry Season) [6].

\subsection{Experimental birds, feeding, design and treatment}

Twelve (12) males and forty-eight (48) females Pearl Guinea fowls of 12 weeks old selected from a flock at the Research Department were used for the study with an average weight of $1.4 \mathrm{~kg}$ and $1.3 \mathrm{~kg}$ for females and males, respectively. Soya bean, wheat bran, maize, tuna fish, Russia fish, premix vitamin, oyster shell, dicalcium phosphate and salt were used to formulate a diet containing 16\%, 18\%, 20\% and 22\% Crude protein levels and $2750 \mathrm{Kca} / \mathrm{kg}$ Metabolizable energy [7]. Feed and water were offered ad libitum in a removable feeding and water troughs. Birds were kept in deep litter floored house of $49.9 \mathrm{~m} \times 8.17 \mathrm{~m} \times 2.4 \mathrm{~m}$. The weather record during the study period is shown in Table 1 . Four (4) hens and one (1) male were each subjected to $16 \% \mathrm{CP}, 18 \% \mathrm{CP}, 20 \% \mathrm{CP}$ and $22 \% \mathrm{CP}$. Each group was replicated three times and reared in three seasons (Dry-December-March, Major Rains-April-July and Minor Rains-August-November) in a $3 \times 4$ factorial experimental design.

\subsection{Housing, Feeding and Medication}

A total of twelve (12) experimental cages were used for rearing the birds, each measuring $1.4 \mathrm{~m} \times 1.34 \mathrm{~m}$ and housed five (5) birds. The floor was concreted, and wood shavings were used as litter for the birds. Removable wooden feeding troughs measuring $0.8 \mathrm{~m} \times 0.04 \mathrm{~m} \times 0.03 \mathrm{~m}$ were used for feeding the growers. A 4.5 -liter watering trough was used for supplying water ad libitum for the growers in each cage. The experimental diets were supplied to the birds ad libitum throughout the experimental period. Vaccination and other routine poultry practices were also carried out.

Table 1 Ingredient and proximate composition (\%) of experiment diets used for the study

\begin{tabular}{|l|l|l|l|l|}
\hline Attributes & $(\mathbf{1 6 \%} \mathbf{C P})$ & $\mathbf{( 1 8 \%} \mathbf{C P})$ & $\mathbf{( 2 0 \%} \mathbf{C P})$ & $\mathbf{( 2 2 \%} \mathbf{C P})$ \\
\hline Ingredients & 61.0 & 60.0 & 58.0 & 55.5 \\
\hline Maize & 2.5 & 5.0 & 6.0 & 9.5 \\
\hline Fish meal (Russia) & 7.0 & 8.0 & 10.0 & 11.0 \\
\hline Fish meal (Tuna) & 7.0 & 8.5 & 10.0 & 10.0 \\
\hline Soya bean & 18.5 & 14.5 & 12.5 & 10.0 \\
\hline Wheat bran & 2.5 & 2.5 & 2.0 & 2.0 \\
\hline Oyster shell & 0.5 & 0.5 & 0.5 & 0.5 \\
\hline Dicalcium phosphate & 0.5 & 0.5 & 0.5 & 0.5 \\
\hline Vitamin Premix & 0.5 & 0.5 & 0.5 & 0.5 \\
\hline Salt & & &
\end{tabular}




\begin{tabular}{|c|c|c|c|c|}
\hline Total & 100 & 100 & 100 & 100 \\
\hline \multicolumn{5}{|c|}{ Proximate Composition \% } \\
\hline Moisture content & 10.5 & 10.5 & 10.0 & 11.0 \\
\hline Protein content & 15.76 & 17.78 & 19.75 & 21.49 \\
\hline Ether extract & 4.0 & 5.5 & 4.0 & 5.0 \\
\hline Ash content & 11.0 & 8.5 & 10.0 & 9.5 \\
\hline Crude fibre & 5.42 & 4.91 & 4.37 & 4.28 \\
\hline ME, kcal/kg & 2,750 & 2,750 & 2,750 & 2,750 \\
\hline
\end{tabular}

Table 2 Weather Records for the Municipality for 2017

\begin{tabular}{|l|l|l|l|}
\hline Variables & $\begin{array}{l}\text { Dryseason } \\
\text { (December-March) }\end{array}$ & $\begin{array}{l}\text { Major Rainy Season } \\
\text { (April-July) }\end{array}$ & $\begin{array}{l}\text { Minor Rainy Season } \\
\text { (August-November) }\end{array}$ \\
\hline Temperature $\left({ }^{\circ} \mathrm{C}\right)$ & 32.0 & 30.25 & 27.0 \\
\hline Rainfall $(\mathrm{mm})$ & 27.28 & 130.0 & 125.05 \\
\hline Humidity $(\%)$ & 65.5 & 81.25 & 84.5 \\
\hline Cloud cover $(\%)$ & 37.50 & 60.00 & 65.25 \\
\hline Sun Hours (hr.) & $103.10 \quad$ Source: World weather online (2017) \\
\hline
\end{tabular}

\subsection{Parameters Measured}

Data on production parameters in terms of feed intake and feed efficiency, hen-day egg production, egg weight, egg mass and reproductive parameters in terms of age at sexual maturity, body weight at sexual maturity, fertility and hatchability were recorded. Eggs were collected daily, identified and stored under a room temperature of $25^{\circ} \mathrm{C}$ for seven days. This was to imitate the environmental conditions of local farmers. Eggs were cleaned, disinfected by fumigation before setting. Candling was performed on day 18 of incubation after which fertile eggs were transferred to the hatcher. Fertility and hatchability were recorded.

\subsubsection{Feed intake and feed conversion ratio}

Feed intake was calculated as the difference between the initial feed offered to birds and the feed left over. Feed conversion ratio (FCR) was computed as the feed intake divided by the total weight gain.

$$
\text { Arithmetically, FCR }=\frac{\text { Total feed intake }(\mathrm{g})}{\text { Total weight gain }(\mathrm{g})}
$$

\subsubsection{Egg weight}

Egg weight was determined by weighing individual eggs collected daily with the use of A\&D Weighing EK-6000i electronic balance.

\subsubsection{Hen day egg production}

Hen day egg production was therefore calculated as the percentage of the number of eggs laid to the number of hen days.

$$
\text { HDEP }=\frac{\text { Number of eggs laid }}{\text { Number of hen days }} \times 100 \%
$$

\subsubsection{Egg mass (g)(EM)}

This was determined by the product of averages of egg weights and henday egg production. 
Egg Mass=Average egg weight $\times$ henday egg production

\subsubsection{Percentage fertility}

Percentage fertility was calculated by expressing the total number of fertile eggs as a percentage of the total number of eggs set.

$$
\text { Arithmetically, } \% \text { Fertility }=\frac{\text { Total number of fertile eggs }}{\text { Total number of eggs set }} \times 100
$$

\subsubsection{Percentage hatchability}

Percentage hatchability was determined as the total number of eggs hatched as a percentage of total number of fertile eggs.

$$
\% \text { Hatchability }=\frac{\text { Total number of Guinea keets hacthed }}{\text { Total number of fertile eggs }} \times 100
$$

\subsubsection{Percentage hatch rate}

The percent hatch rate is the percentage of total eggs hatched out.

$$
\text { Percent Hatch Rate }=\frac{\text { Total number of eggs hacthed out }}{\text { Total number of eggs set in incubator }} \times 100
$$

\subsection{Internal and External Egg Characteristics}

The destructive method was applied to measure internal and external egg characteristics. These included yolk weight, albumen weight, yolk height, albumen height, shell weight, shell thickness and Egg diameter [8].

\subsubsection{Shell weight}

To Measure the weight of shell, the eggs were broken down and after removal of egg albumen, the eggshell was dried and cleaned with the help of cotton and weighed with the help of an A\&D Weighing EK-6000i

\subsubsection{Yolk height}

For internal egg quality traits, individual egg samples were broken out on a flat glass without disturbing the yolk. Internal parameters measured were measured as the height of the yolk at the midpoint with a spherometer.

\subsubsection{Albumen height}

This was measured as the height of the chalazae at a point midway between thinner and outer circumference of the white with a spherometer.

\subsubsection{Shell thickness}

This is the thickness of the dry eggshell measured with a screw gauge. The mean of three points (the narrow, broad and middle) was taken as shell thickness.

\subsubsection{Haugh unit (HU)}

Haugh unit (HU) was calculated using Raymond Haugh's rating (Haugh, 1937). HU= $100 \log \left(\mathrm{H}-1.7 w^{0.37}+7.6\right)$, where, $\mathrm{HU}=$ Haugh Unit, $\mathrm{H}=$ Albumen height $(\mathrm{mm})$ and $\mathrm{W}=$ Egg weight ( $\mathrm{g}$ ).

\subsection{Data Analysis}

Data collected were analyzed using General Linear Model (GLM) procedure of Statistical Analysis System (SAS for Windows, version 7) with season and dietary crude protein level as the main effects. The means were separated by using the probability of difference (PDIFF) procedure of SAS [9]. Unless otherwise stated, all statements of significance were based on testing at the $p \leq 0.05$ levels. 


\section{Results}

\subsection{Effect of different dietary crude protein levels on production traits}

Effect of different dietary crude protein levels on production and reproductive performance has been presented in Table 3. Varying the concentration of crude protein did not significantly influence $(\mathrm{p}<0.05)$ Feed Intake (FI), Feed Conversion Ratio (FCR) and Egg Weight (EW). Varied crude protein levels significantly influenced $(\mathrm{p}<0.05)$ hen-day egg production (HDEP) and egg mass (EM). The highest hen-day egg production was obtained from birds fed $22 \%$ crude protein. Similarly, egg mass increased with increasing dietary protein level and the highest $(\mathrm{p}<0.05)$ was observed when the diet contained 22\% CP Hen-day egg production and egg mass were both lowest at birds fed $16 \%$ crude protein.

Table 3Effect of different dietary protein level on production traits

\begin{tabular}{|l|l|l|l|l|l|l|}
\hline Treatment/ Parameters & $\mathbf{( 1 6 \%} \mathbf{C P})$ & $\mathbf{( 1 8 \%} \mathbf{C P})$ & $\mathbf{( 2 0 \% \mathbf { C P } )}$ & $\mathbf{( 2 2 \%} \mathbf{C P})$ & S. Error & P-value \\
\hline Feed intake & 106.43 & 103.87 & 106.37 & 106.67 & 1.13 & 0.28 \\
\hline Egg weight at first laying (g) & $30.83^{\mathrm{c}}$ & $33.36^{\mathrm{b}}$ & $33.38^{\mathrm{b}}$ & $35.12^{\mathrm{a}}$ & 0.49 & 0.01 \\
\hline Egg Weight (g) & 40.97 & 41.56 & 41.73 & 41.64 & 0.40 & 0.55 \\
\hline Feed conversion ratio & 2.60 & 2.50 & 2.55 & 2.56 & 0.04 & 0.40 \\
\hline Hen-day egg production (\%) & $25.93^{\mathrm{c}}$ & $30.13^{\mathrm{b}}$ & $28.41^{\mathrm{b}}$ & $32.96^{\mathrm{a}}$ & 1.03 & 0.01 \\
\hline Egg mass (g/bird/day) & $10.65^{\mathrm{c}}$ & $12.57^{\mathrm{b}}$ & $12.91^{\mathrm{b}}$ & $13.86^{\mathrm{a}}$ & 0.50 & 0.01 \\
\hline
\end{tabular}

Means bearing different superscripts in the same row are significantly different $(\mathrm{P}<0.05)$,

\subsection{Effect of different dietary protein level on reproductive traits}

Age at sexual maturity was significantly influenced by dietary crude protein level $(\mathrm{p}<0.01)$ (Table 4). Increasing dietary protein reduced the number of days the bird reached sexual maturity. The shortest was recorded with the birds fed $22 \%$ dietary protein whilst the $16 \%$ dietary protein recorded the longest. There was no significant effect (p>0.05) of different dietary crude protein level on fertility of egg set. Similar results were obtained for hatchability of egg set and hatchability of fertile eggs.

Table 4Effect of different dietary protein level on reproductive traits

\begin{tabular}{|l|l|l|l|l|l|l|}
\hline Treatment/ Parameters & $(\mathbf{1 6 \%} \mathbf{C P})$ & $\mathbf{( 1 8 \%} \mathbf{C P})$ & $\mathbf{( 2 0 \% \mathbf { C P } )}$ & $\mathbf{( 2 2 \%} \mathbf{C P})$ & S. Error & P-value \\
\hline Age at sexual maturity (days) & $194.00^{\mathrm{a}}$ & $180.00^{\mathrm{c}}$ & $187.00^{\mathrm{b}}$ & $170.00^{\mathrm{d}}$ & 2.35 & 0.01 \\
\hline Fertility (\%) & 66.61 & 62.35 & 67.66 & 69.82 & 2.91 & 0.11 \\
\hline Hatchability of egg set (\%) & 48.04 & 48.79 & 45.33 & 51.16 & 4.73 & 0.85 \\
\hline Hatchability of fertile eggs (\%) & 68.18 & 65.60 & 64.31 & 62.49 & 4.98 & 0.87 \\
\hline
\end{tabular}

Means bearing different superscripts in the same row are significantly different $(\mathrm{P}<0.05)$,

\subsection{Effect of dietary protein on egg characteristics}

The main effect of different dietary crude protein level on egg characteristics is presented in Table 5. Different dietary protein level had no effect on internal characteristic of eggs except in yolk weight. Yolk weight was highest $(\mathrm{p}<0.05)$ in $18 \%$ crude protein level followed by $20 \%$ crude protein. The lowest egg yolk weight was recorded in diet containing $16 \%$ crude protein. Shell weight and shell thickness showed no significant difference $(\mathrm{p}>0.05)$ in all the crude protein levels. Similarly, different dietary crude protein level had no significant effect ( $p>0.05)$ in egg diameter and Haugh unit. 
Table 5 Effect of different dietary crude protein level on egg characteristics

\begin{tabular}{|l|l|l|l|l|l|l|}
\hline Treatment/Parameters & $\mathbf{( 1 6 \%} \mathbf{C P})$ & $\mathbf{( 1 8 \%} \mathbf{C P})$ & $\mathbf{( 2 0 \% \mathbf { C P } )}$ & $\mathbf{( 2 2 \%} \mathbf{C P})$ & S. Error & P-value \\
\hline Haugh Unit & 47.13 & 46.87 & 47.71 & 46.23 & 1.27 & 0.71 \\
\hline Egg Diameter (mm) & 4.10 & 4.18 & 4.02 & 4.02 & 0.17 & 0.73 \\
\hline Yolk height (mm) & 2.35 & 2.73 & 2.63 & 2.53 & 0.18 & 0.24 \\
\hline Yolk weight (g) & $17.00^{\mathrm{c}}$ & $20.33^{\mathrm{a}}$ & $19.67^{\mathrm{ab}}$ & $18.89 \mathrm{~b}$ & 1.19 & 0.04 \\
\hline Albumin height (mm) & 2.01 & 2.20 & 2.13 & 1.97 & 0.09 & 0.09 \\
\hline Albumin weight (g) & 16.22 & 16.78 & 16.22 & 15.67 & 0.97 & 0.73 \\
\hline Shell weight (g) & 7.00 & 7.56 & 7.33 & 5.78 & 0.69 & 0.07 \\
\hline Shell thickness (mm) & 0.056 & 0.062 & 0.061 & 0.055 & 0.003 & 0.23 \\
\hline
\end{tabular}

Means bearing different superscripts in the same row are significantly different $(\mathrm{P}<0.05)$,

\subsection{Effect of season on production traits}

The effect of season on production and reproductive traits has been presented in Table 6 . All the production parameters were significantly $(\mathrm{p}<0.05)$ influenced by season. Feed intake was higher in the minor rainy season (August-November) where temperatures were relatively lower. The lowest value was recorded in the dry season where temperatures were higher. The analysis showed that feed consumption increased from the dry season to the minor rainy season.

Table 6 Effect of Season on production traits

\begin{tabular}{|l|l|l|l|l|l|}
\hline Treatment/Parameter & $\begin{array}{l}\text { December-March } \\
\text { (Dry Season) }\end{array}$ & April-July (Major & August-November & S. Error & $\begin{array}{l}\text { P- } \\
\text { value } \\
\text { (Minor Reason) } \\
\text { Season) }\end{array}$ \\
\hline Feed Intake (g) & $94.21^{\mathrm{c}}$ & $106.48^{\mathrm{b}}$ & $116.81^{\mathrm{a}}$ & 0.98 & 0.01 \\
\hline Feed Conversion Ratio & $2.38^{\mathrm{b}}$ & $2.49^{\mathrm{c}}$ & $2.77^{\mathrm{a}}$ & 0.03 & 0.01 \\
\hline Monthly Egg Production & $24.5^{\mathrm{b}}$ & $42.16^{\mathrm{a}}$ & $13.08^{\mathrm{c}}$ & 0.70 & 0.01 \\
\hline Egg Weight (g) & $39.61^{\mathrm{c}}$ & $42.70^{\mathrm{a}}$ & $42.12^{\mathrm{b}}$ & 0.50 & 0.01 \\
\hline Hen Day (\%) & $27.22^{\mathrm{b}}$ & $46.85^{\mathrm{a}}$ & $14.00^{\mathrm{c}}$ & 0.95 & 0.01 \\
\hline Egg mass (g/bird/day) & $10.80^{\mathrm{b}}$ & $20.03^{\mathrm{a}}$ & $6.67^{\mathrm{c}}$ & 0.58 & 0.01 \\
\hline
\end{tabular}

Means bearing different superscripts in the same row are significantly different $(\mathrm{P}<0.05)$,

\subsection{Effect of season on reproductive traits}

The effect of season on fertility and hatchability of Guinea fowl eggs has been presented (Table 7). There was significant effect $(p<0.05)$ of season on fertility. Among the seasons the highest fertility was observed in the dry season (DecemberMarch). This was followed by the major rainy season (April-July) and the lowest in the minor rainy season (AugustNovember).

Table 7 Effect of Season on production traits

\begin{tabular}{|l|l|l|l|l|l|}
\hline Treatment/Parameter & $\begin{array}{l}\text { December- } \\
\text { March (Dry } \\
\text { Season) }\end{array}$ & $\begin{array}{l}\text { April-July } \\
\text { (Major Rainy } \\
\text { Season) }\end{array}$ & $\begin{array}{l}\text { August-November } \\
\text { (Minor Rainy } \\
\text { Season) }\end{array}$ & S. Error & $\begin{array}{l}\text { P- } \\
\text { value }\end{array}$ \\
\hline Fertility (\%) & $77.58^{\mathrm{a}}$ & $63.33^{\mathrm{b}}$ & $58.75^{\mathrm{c}}$ & 1.85 & 0.01 \\
\hline Hatchability of egg set (\%) & 48.65 & 53.64 & 42.71 & 4.09 & 0.19 \\
\hline $\begin{array}{l}\text { Hatchability of fertile eggs } \\
(\%)\end{array}$ & 63.18 & 68.94 & 63.31 & 4.31 & 0.56 \\
\hline
\end{tabular}




\subsection{Effect of season on egg characteristics}

The results for quality traits of egg are presented in table 8. All egg quality traits measured varied significantly ( $\mathrm{p}<0.05$ ) with season except yolk weight and shell weight. Haugh unit was highest $(p<0.05)$ in the minor rainy season and was followed by major rainy season. The lowest value of Haugh unit was recorded in the dry season. Season did not show any significant effect $(\mathrm{p}<0.05)$ on yolk weight. Albumin weight was significantly $(\mathrm{p}<0.05)$ influenced by season. Albumin weight was highest in the minor rainy season and lowest in the dry season.

Table 8Effect of season on egg characteristics

\begin{tabular}{|l|l|l|l|l|l|}
\hline $\begin{array}{l}\text { Treatment/ } \\
\text { Parameter }\end{array}$ & $\begin{array}{l}\text { December- } \\
\text { March (Dry } \\
\text { Season) }\end{array}$ & $\begin{array}{l}\text { April-July } \\
\text { (Major Rainy } \\
\text { Season) }\end{array}$ & $\begin{array}{l}\text { August- } \\
\text { November } \\
\text { Minor } \\
\text { Season) }\end{array}$ & $\begin{array}{l}\text { Standard } \\
\text { Error }\end{array}$ & P-value \\
\hline Haugh Unit & $45.53^{\mathrm{b}}$ & $46.04^{\mathrm{b}}$ & $49.38^{\mathrm{a}}$ & 1.10 & 0.04 \\
\hline Egg Diameter (cm) & $3.91^{\mathrm{c}}$ & $4.00^{\mathrm{b}}$ & $4.33^{\mathrm{a}}$ & 0.14 & 0.02 \\
\hline Yolk height (cm) & $2.40^{\mathrm{c}}$ & $2.47^{\mathrm{b}}$ & $2.81^{\mathrm{a}}$ & 0.16 & 0.03 \\
\hline Yolk weight (g) & 18.25 & 18.75 & 19.92 & 1.03 & 0.27 \\
\hline Albumin height (cm) & $1.92^{\mathrm{b}}$ & $1.96^{\mathrm{b}}$ & $2.35^{\mathrm{a}}$ & 0.08 & 0.01 \\
\hline Albumin weight (g) & $14.58^{\mathrm{c}}$ & $16.33^{\mathrm{b}}$ & $17.75^{\mathrm{a}}$ & 0.84 & 0.04 \\
\hline Shell weight (g) & 6.75 & $6.33^{\mathrm{a}}$ & 7.67 & 0.60 & 0.09 \\
\hline Shell thickness (mm) & $0.05^{\mathrm{b}}$ & $0.05^{\mathrm{b}}$ & $0.06^{\mathrm{a}}$ & 0.01 & 0.01 \\
\hline
\end{tabular}

Means bearing different superscripts in the same row are significantly different $(\mathrm{P}<0.05)$,

\section{Discussion}

\subsection{Effect of different dietary crude protein levels on production traits}

Feed intake (FI) was not significantly affected in this study and this trend is corroborated with the study of Nahashon et al. [10] which showed no significant effect on feed consumption. Similar study conducted by Nahashon et al. [11] had shown that birds fed higher concentration of $24 \%$ crude protein diet consumed more feed than those fed diet containing $20 \%$ and $22 \%$ crude protein. Similarly, birds consuming diets containing $21 \%$ crude protein was significantly higher than that of birds fed diets containing 19 and 17\% crude protein [10]. Latshaw and Zhao [12]reported that increased dietary protein level increased feed intake in layers. Perween et al. [13] showed that the difference might have resulted from different energy levels in the diet and since the diet for this study was Isocaloric no difference was recorded.

The report established no significant effect of different dietary protein level on egg weight. This was not expected as Almeida et al. [14] had reported significant effect as diet 18\% CP increased egg weight. Physiologically, protein is an important component of egg [15] and higher CP content determines higher CP deposition in the egg. Positive linear effect of dietary crude protein level had been observed in Japanese quail [16].However, the recent study has demonstrated that egg weight was not influenced by level of protein in diet [17].It has been observed that calculated average daily intake of protein by layers fed $13.38 \%$ may be sufficient to meet the optimum production at that protein level. It is shown that even in low protein diets all the essential amino acids are met as per the requirement of protein threshold. Layers can produce quality egg weight on diet containing 14 to $15 \%$ balanced protein compared with those fed a diet of $17 \%$ crude protein [18].

This study demonstrated no significant effect of different dietary protein level on Feed Conversion Ratio (FCR). An improved FCR and energy efficiency with the increased level of CP or amino acids had been observed in Guinea fowls during initial growth period [19]. Kaur et al. [20] also reported that FCR improved with increasing essential amino acid levels only during early growth phase. Earlier report of Adeyemo et al. [2] divergently showed that feed conversion ratio was the best with increasing dietary protein. Dietary protein recorded comparable feed efficiency with increased dietary protein showing highest efficiency in Japanese quails [20]. Shim et al. [21] showed that feed efficiency was observed during the laying phase. 
This study showed that hen-day egg production increased with increasing dietary protein level. Higher protein of $22 \%$ $\mathrm{CP}$ showed highest egg production while $16 \% \mathrm{CP}$ recorded the lowest and is supported by the report of Keshavarz and Jackson[22] and Adeyemo et al. [2] which showed that increased protein inclusion in poultry diet increased level of egg production. However, the study of Nahashon et al. [11] had established that even diets lower than $16 \%$ CP (14\% CP) exhibited higher hen-day egg production than birds fed 16 and $18 \%$ crude protein diets. Highest hen-day egg production of $39.96 \%$ for $22 \%$ CP was similar to the study of Nahashon et al. [11] of 31\% of birds on $14 \%$ than those fed 16 and $18 \mathrm{CP}$ diets, respectively. This suggests that, physiologically, $14 \% \mathrm{CP}$ seemed adequate for pearl Guinea fowl layers. In circumstances such as decreased dietary protein, increasing production may be due to increased expenditure of energy in catabolism to increase energy expenditure and utilization of excess amino acid [23].

\subsection{Effect of different dietary protein level on reproductive traits}

Age at sexual maturity was significant and the findings of this study is in the range of Annor et al. [7]who reported 180 days for local Guinea fowl, 224 days for bird under free range and 154 for birds under intensive rearing. No significant influence of dietary protein on age at sexual maturity and age at 50 per cent egg production was observed [24]. Earlier studies have shown that breeders fed higher protein diet tend to produce eggs with significantly lower fertility and hatchability [25].Other studies have found no effect on fertility and hatchability of feeding diets containing $9-15 \%$ crude protein to breeders or diets containing 10-16\% crude protein throughout the laying period [26].

Decreased fertility and hatchability could be ascribed to diet composition in particular, daily protein intake during the laying period. The estimated dietary requirement of protein for laying bird spans around $14-18 \%$ crude protein, however, protein has no significant effect on fertility and a 12\% poultry diet is adequate to support higher fertility [27]. King'ori et al. [28] had observed that maternal protein has no effect on hatchability. The study of Arscott and Parker [29] showed that not even the male factor increased fertility when dietary protein was increased. Leveille et al. [30] showed that calculated amino acid content of diets of $16.9 \%$ exceeds the amino acid requirement for maintenance of optimum reproductive performance and that diet of $16 \%$ will support fertility and hatchability of poultry eggs. Novalk et al. [31] reported that yolk quality was directly proportional to dietary crude protein suggesting that amino acid required for albumin synthesis may have been limited at lower crude protein levels. The increase in yolk percentage was probably associated with reduction in albumin percentage and egg size. However, it has been demonstrated that egg yolk is produced in the liver and may not be affected by reducing dietary crude protein [31,32]. It has been reported that increased dietary crude protein may have the potential to increase egg weight and this may increase fertility and hatchability and that dietary protein of $18 \%$ supports embryonic development and survival $[28,33]$.

\subsection{Effect of dietary protein on egg characteristics}

These finding is confirmed by Novak et al. [31] who found that yolk weights were decreased with feeding low crude protein diets. As dietary protein levels increased, yolk weights significantly increased. These results were in agreement with those of Gunawardana et al. [34]. Yolk weight was indirectly proportional to dietary crude protein only in younger hens from [21]. In a previous report [31], yolk weight was directly proportional to dietary crude protein, suggesting that the amino acids required for albumen synthesis (production requirements) may have been limited at the lower CP levels. The increase in yolk weight was probably associated with the reduction in albumen weight. It was, however, noted that egg yolk is produced in the liver and continuously accumulated in the ovum until ovulation, and may not be affected by reducing dietary crude protein $[31,32]$.

The results showed that increases in dietary protein level did not improve egg quality. The results of this study is adminiculated by Janquieira et al. [35], who had earlier shown that $16 \%$ dietary protein was sufficient for laying hens without decreasing egg quality. Physiologically, the protein requirement probably had been reached with the lowest evaluated level (16\%). This suggests that supplying protein in excess does not improve egg characteristics. Leeson et al. [25] has inferred that dietary protein in excess causes higher nitrogen in faeces and not necessarily improving egg quality traits. This indicates that increasing dietary protein level will not result in significant retention. Almeida et al. [25] reported that apart from Haugh unit external and internal characteristics of egg were not affected by dietary protein level. Shim et al.[21] did not observe any effect of crude protein levels of 18,20 , and $22 \%$ on egg qualities of layers. Zimmermann and Andrews [36] did not find any positive or negative effect on shell quality and Haugh units score with 2 levels of CP (14.6 and 15.5\%) in layer diets. In addition, De Mendonca and Lima [37] did not observe any impact of dietary CP level on egg albumen.

\subsection{Effect of season on production traits}

The feed intake in this study is in the range of the report of Annor et al [7]. The effect of hot environment on the body of birds is enormous and a lot of physiological activities undergo changing including feed intake (Donald, 2003). As 
temperature increases feed intake decrease [38] resulting from reduction in tissue metabolism through adaptive physiological and biochemical mechanisms. Dry hot weather dries the feed and Donald [39] concluded that birds had $38 \%$ more dry matter intake of moist feed as compared with dry feed at $33^{\circ} \mathrm{C}$. Maintenance requirement in leghorn bird is reduced by $30 \mathrm{kcal} /$ day when ambient temperature rises from $21^{\circ} \mathrm{C}$ to $38^{\circ} \mathrm{C}$ [38]. Feed intake reduces above $28^{\circ} \mathrm{C}$. Alves [40] had reported that in relatively lower temperature birds lose considerable energy trying to maintain their body temperature and this should be compensated by increasing feed intake.

The results indicate that the highest feed conversion ratio (FCR) was recorded in the major rainy season whilst the lowest in performance was in the minor rainy season (August-November) and the effect was significant $(p<0.05)$. This outcome is supported by earlier report that hot and cold periods exert s detrimental effect on feed efficiency [41]. The result of this study has amply demonstrated that season had significant effect on hen-day egg production and egg mass $(\mathrm{p}<0.05)$. Hen-day egg production and egg mass were highest during the major rainy season and lowest in the minor rainy season. The result is concurred by earlier report that increased temperature caused a daily feed intake reduction resulting in inadequate energy for maintenance and for egg production [42]. In the current study, major rainy season produced higher number of eggs that might have resulted in enhanced egg mass [43], since egg mass is the product of egg no and egg weight.

\subsection{Effect of season on fertility and hatchability}

There is positive correlation between season, especially, factors such as temperature, humidity and photoperiod on fertility [28, 44]. Mahmoud et al. [45] showed that high environmental temperature and humidity depress egg internal qualities thereby reducing the fertility potential of set eggs. Jesuyon and Salako [46] reported that wet season gave the best results in fertility and this shows divergence from the current result which shows the highest fertility in the dry season. The mean fertility values in this study is better than fertility of local Guinea fowls (40-58\%) and comparable to fertility of commercial Guinea fowl production [7]. This report is confirmed by the study of Jayarajan [47] in Rhode Island Red during hot season, though McDaniel et al. [48] had reported no significant effect of season on fertility. Significant differences $(p>0.05)$ were not established between season as egg hatchability was subjected to seasonal influences. Neither hatchability of egg set, nor hatchability of fertile eggs were significant $(p<0.05)$. The result of this study is confirmed by earlier report which demonstrated no significant effect of season on hatchability [49]. The drier the atmosphere, the greater the water loss, thus egg vitality is also lost, affecting hatchability and chick quality [50].

\subsection{Effect of season on egg characteristics}

The significance of Haugh unit is to take into consideration the size of an egg in terms of weight and albumin content which is the measure of egg quality [51]. The higher the Haugh unit, the better the quality and follows that the minor rainy season produced eggs with better quality. The lower values in the dry season and the major rainy season may be attributed to higher temperatures and humidity in the period which negatively affected the quality [49]. Yolk weight values in this study were higher than $14.26 \pm 0.74 \mathrm{~g}$ and $12.7 \mathrm{~g}$ reported by Dudusola [52] and Nowaczewski [52] in local Guinea fowls, respectively. This result contradicts the report of Ojedapo (2013) who found significant effect ( $\mathrm{p}<0.05)$ of season on all internal characteristics of Isa Brown layers chicken. The mean albumin weight was lower than values reported earlier in local (21.5g) and exotic French Guinea fowl (31.3g) [52]. Oyedapo [54] had reported higher albumin weight in the early and late wet seasons in Nigeria which coincides with the major and minor rainy seasons in Ghana. The improved egg internal characteristics is imputable to the period of rainfall as rainfall increases pituitary release of gonadotropins luteinizing hormone and follicle stimulating hormone and, therefore, stimulates pre-ovulatory follicular growth [55]and release of larger yolk which influences yolk weight and height, albumin height and egg diameter [56].

\section{Conclusion}

Increasing Dietary protein has potential to promote favourable results in production and reproductive traits in Guinea fowls, nevertheless, $16 \%$ crude protein diet is sufficient to support optimum egg production, fertility and hatchability, and egg characteristics. Dietary protein only improves yolk quality, but not other egg characteristics. Similarly, Season of breeding has influence on production traits, fertility and hatchability as well as egg characteristics. Breeding should be planned to take advantage of the major rainy season which support increased egg production and egg weight. Wet period within the year improves egg external and internal quality traits. 


\section{Compliance with ethical standards}

\section{Acknowledgments}

The authors are grateful to the Department of Animal Science Education, Faculty of Agriculture Education, University of Education, Winneba for providing facilities for this study.

\section{Disclosure of conflict of interest}

Authors have declared that, no conflict of interests exist.

\section{References}

[1] Ashitey E. Ghana Poultry Report Annual. Global Agricultural Information Network. Accra, Ghana. 2013.

[2] Adeyemo GO, Abioye SA, Aderemi FA. The effect of varied Dietary crude protein level with balanced amino acid on performance and egg quality characteristics of layers at first laying face.Journal of Food and Nutrition Sciences.2012; (3): 526-529.

[3] Nwagu BI. Factors affecting fertility and hatchability of guinea fowl eggs in Nigeria. World's Poultry Science Journal. 1997;Vol. 53 (3):279-286.

[4] Konlan SP, Avornyo FK, Karbo N, Sulleyman A. Increasing Guinea eggs availability and Hatchability in the Dry Season. Journal of World's Poultry Research. 2011; Vol 1(1):1-3

[5] Adjetey ANA. Comparative Growth Performance of Growing Indigenous Guinea Fowl (Numida meleagris) from the Upper East, Upper West and Northern Regions of Ghana. BSc. Thesis. University for Development Studies, Department of Animal Science, Tamale, Ghana.2006.

[6] Meteorological Services Department (MSD) Annual Reports. Mampong Municipal Assembly, Mampong-Ashanti, Ashanti Region, Ghana.2016.

[7] Annor SY, Apiiga SY, Ahiaba J. Guinea Fowl production: A handbook. Accra, Ghana: Quality type Ltd.2013.

[8] Kyere CG, Annor SY, Kagya-Agyemang JK, Korankye O. Effect of egg size and day length on reproductive and growth performance, egg characteristics and blood profile of the Guinea fowl. Livestock Research for Rural Development. 2017. Volume 29, Article \#180.http://www.lrrd.org/lrrd29/9/kyer29180.html

[9] Statistical Analysis System (SAS). User's Guide. SAS/STAT® 9.2, Cary, NC: SAS Institute Inc, 2008.

[10] Nahashon SN, Adefope NA, Amenyenu A, Wright D. Effect of varying concentration of dietary crude protein and metabolizable energy on laying performance of pearl grey Guinea fowl hens. Journal of Poultry Science. 2006;86:1793-1799.

[11] Nahashon SN, Adefope NA, Amenyenu A, and Wright D. Effect of varying concentration of dietary crude protein and metabolizable energy on growth performance of pearl grey Guinea fowl hens.Journal of Poultry Science, 2007;72:1349-1358.

[12] Latshaw JD, Zhao L. Dietary protein effect on hen performance and nitrogen excretion. Journal of Poultry Science 2011; 90:99-106.

[13] Perween S, Kumar K, Chandramoni KS, Kumar SP, Kumar M, Dey A. Effect of feeding different dietary levels of energy and protein on growth performance and immune status of Vanaraja chicken in the tropics. Journal ofVeterinary World.2016; Vol. 9(8):893-899.

[14] Almeida VR, Dias AN, Bueno CFD, Couta FAP, Rodriguez PA, Nogueira WCL, Faria-Filho DE. Crude protein and metabolizable energy levels for layers reared in hot climates. JournalRevistaBraseira de CiensiaAvicola.2012; $14(3)$.

[15] Leeson S, Summer JD. Broiler breeder production. University Books, Guelph, Ontario, Canada.2000

[16] Pinto R, Ferreira AS, Albino LFT, Gomes PC, DeVargas JC. (2002). Protein and Energy level for laying Japanese quails. R. Bras Zootec. 2002; 314):1806-1814.

[17] Rama-Rao SVV, Ravindran T, Srilatha A, Panda K, Raju MVLN. Effect of dietary concentrations of energy, crude protein, lysine, and methionine on the performance of White Leghorn layers in the tropics.JournalofApplied Poultry Research, 2011; Vol. 20:528-541. 
[18] Khajali F, Khoshouie EA, Dehkordi SK, Hencolian M. Production performance and egg quality of hy-line W36 laying hens fed reduced-protein diets at a constant total Sulphur amino acid: lysine ratio. Journal of. Applied Poultry Research.2008; Vol. 17:390-397

[19] Mandal AB, Pathak NN, Singh H. Energy and protein requirements of guinea keets (Numidia meleagris) as meat birds in a hot Climate. Journal of the Science of Food and Agriculture.1999; Vol. 79: 523-531.

[20] Kaur S, Mandal AB, Singh KB, Kadam MM. The response of Japanese quail to dietary energy levels and graded essential amino acids levels on growth performance and immune competence. Journal of Livestock Science Poultry Science. 2008; 92(10):2687-2696)

[21] Shim MY, Sing E, Billard L, Aggrey SE, Paeti GM, Sodsee P. (2013). Effect of balanced dietary protein level on egg quality parameters of individual commercial layers. Journal of Poultry Science. 2013; 92:2687-2696.

[22] Keshavarz K, Jackson ME. Performance of growing pullets and laying hens fed low protein, amino acidsupplemented diets. Journal of Poultry Science. 1992; 7(5): 905-918.

[23] Macleod MG. (1997). Effect of amino acid balance on energy: protein ratio and on energy and nitrogen metabolism in male chickens. Journal of Britain Poultry Science. 1997; 38:405-411

[24] Sangilimadan K, Rajini RA, Babakaran R, Barakerishnan V, Murugan M. Effect of dietary protein on layer Japanese quail (Corturnixcorturnix) in tropics. Tamilnadu Journal of Veterinary and Animal Science. 2012; 8(5):271-278

[25] Leeson S, Summer JD. Broiler breeder production. University Books, Guelph, Ontario, Canada.1991.

[26] Lopez G, Leeson S. Response of broiler breeders to low-protein diets. 1. Adult breeder performance. Journal of Poultry Science.1995; Vol. 74:685-695.

[27] Alsobayel AA. Effect of protein diet and age on fertility and hatchability parameters on Saudi Arabian Baladi chicken.Journal of King Saudi University. 1992; 4:47-54.

[28] King'Ori AM, Tuitoek JK, Muiriri HK, Wachira AM. Effect of dietary protein levels on egg production hatchability and post-hatch offspring performance of indigenous chicken of Kenya. International Journal of Poultry Science. 2010; 9:324-329.

[29] Arscott GH, Parker JE. Dietary protein and fertility of male chicken. Journal of Nutrition.1963; 80:311-314.

[30] LeveilleGA, Shapiro R, Fisher H. Amino acid requirement for maintenance in the adult rooster. IV The requirement for methionine, cysteine, phenylalanine, tyrosine and tryptophan: the adequacy of the determined requirement.ibid. $1960 ; 72: 8$

[31] Novak C, Yakout HM, ScheidelerSE.The effect of dietary protein level and total sulfur amino acid: Lysine ratio on egg production parameters and egg yield in Hy-Line W-98 hens. Journal of Poultry Science.2006; 85: 2195-2206.

[32] Hiramoto K, Nuramatsu T, Okumura J. (1990). Protein synthesis in tissues and the whole body of laying hens during egg formation. Poultry Science. 1990; 69:264-269.

[33] Ugurlu M, Akdag F, Teke B, Salman M. Effect of protein in diet and sex ratio on egg production, egg and hatching chick weight, fertility, hatchability and embryonic mortality in pheasants (Phasianuscolchicus). Brazilian Journal of Poultry Science. 2017; 19(2)231-238.

[34] Gunawardana P, Roland DA, Sr-Bryant MM. Effect of energy and protein on performance, egg components, egg solids, egg quality, and profits in molted Hy-Line W-36 hens. Journal of Applied Poultry Research. 2008.

[35] Junqueira OM, De LaurentizAC,Filardi RS, RodriguesEA, Casertelli EM. Effect of energy protein levels on egg quality and performance of laying hens at early second production cycle. Journalof Applied Poultry Research 2006; 15:110-115.

[36] Zimmermann NG, Andrews DK.(1987). Comparison of several induced molting methods on subsequent performance of Single Comb White Leghorn hens. Journal of Poultry Science.1987; 66: 408-417.

[37] De Mendonca Jr CX, Lima FR.Effect of dietary protein and methionine levels on forced molt performance of laying hens. Brazilian Journal of Veterinary Research and Animal Science.1999; 36: 332-338.

[38] Quiniou N, Dubois S, Noblet J. Voluntary feed intake and feeding behaviour of group-housed growing pigs are affected by ambient temperature and body weight. Livestock Production Science.2000; Vol. 63: 245-253.

[39] Donald JPE. Environmental control options under different climatic conditions. World's Poultry Science Journal, 1998; 14: 22-27. 
[40] Alves FMS, Felix GA, Almeida Paz ICL, Nääs IA, Souza GM, Caldara FR, Garcia RG. Impact of exposure to cold on layer production. Journal of RevistaBraseira de CiensiaAvicola, 2012; Vol. 14:3.

[41] Mashaly MM, Hendricks GL, Kalama MA, Gehad AE, Abbas AO, Patterson PH.Effect of heat stress on production parameters and immune responses of commercial laying hens. Poultry Science. 2004; 83:889-894.

[42] Lin H, Mertens K, Kemps B, Govaerts T, De Ketelaere B, De Baerdemaeker J, Decuypere E, Buyse J. New approach of testing the effect of heat stress on eggshell quality: Mechanical and material properties of eggshell and membrane. Journal of Brazilian Poultry Science.2004; Vol. 45:476-482.

[43] Aygun A, Olgun 0. The effect of non- feed and feed withdrawal molting methods on molt and post molt performance in laying hens. Trends Animal Veterinary Science.2010; 1 (2): 45-48.

[44] Islam SS, Hossain MB, Khan MKA. Effect of Genotype Age and Season on Hatchability of Eggs. Bangla. Journal of Animal Science.2008; Vol. 37(1):17-22.

[45] Mahmoud KZ, Beek MM, Sheideller SE, Foreman MF, Anderson KP, Kachman SD. Acute high temperature and calcium-estrogen relationship in the hen. Journal of Poultry Science. Vol. 1996; 75:1555-1562.

[46] Jesuyon OMA, Salako AE. Effect of Seasons on the Reproductive Performance of Bovan Nera and Isa Brown Parent-stock Chickens in a Hot Humid Environment. International Journal of Animal and Veterinary Advances. 2012; Vol. 5(6): 212-21.

[47] Jayarajan S. Seasonal variation in fertility and hatchability of chicken eggs. Indian Journal of Poultry Science. 1992; Vol. 27(1): 36-39.

[48] McDaniel CD, Brament RK, Wilson JC, HawuthB. Fertility of male and female broiler breeders following exposure to elevated ambient temperature. Journal of Poultry Science.1995; Vol. 75: 1029-10.

[49] Uddin SM, Tareque AMM, Howlider M, Khan J, Ahmed S. Effect of dietary protein and energy level on the performance of Starcross layers. 1992.

[50] Belitz HD, Grosch W, Schieberle P. Food Chemistry. 4. ed. Berlin, Heidelberg: Springer Berlin Heidelberg. 2009; pg1070.

[51] DunnI.Improving the Safety and Quality of Eggs and Egg Products: Egg Chemistry, Production and Consumption. 2011.

[52] Dudusola IO. Comparative evaluation of internal and external qualities of eggs from quail and guinea fowl. International Research Journal of Plant Science.2010; Vol. 1(5): 112-115.

[53] Nowaczewski S, WitkiewiczK,Frątczak M, Kontecka H, Rutkowski A, Krystianiak S, Rosiński A. Egg quality from domestic and French guinea fowl. NaukaPrzyr. Technol. 2008; 2(2): 8.

[54] Ojedapo LO. Effect of age and season on egg quality traits of Isa Brown layer strain reared in derived Savanna Zone of Nigeria.Transnational Journal of Science and Technology. 2013; Vol.3 (7):48-60.

[55] McCee EA, Hsueh AJ. Initial and cyclic recruitment of ovarian follicles. Journal of Endocrine Reviews.2000; Vol. 21:200-214.

[56] Hillier SG. Gonadotropic control of ovarian follicular growth and development. Journal of Molecular and Cellular Endocrinology.2001; Vol. 179:39-46.

\section{Author's short biography}

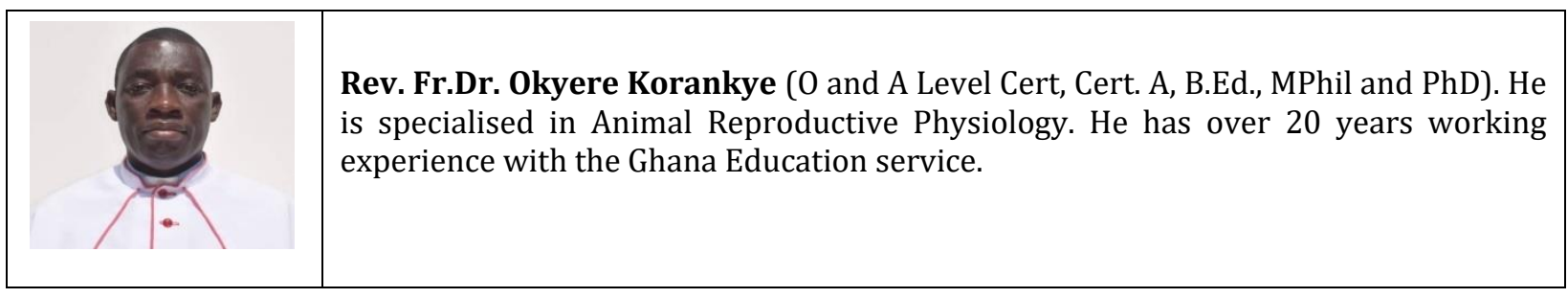




Prof. S. Y. Annor \{BSC, MSC, PhD, PGC (Education, Research methodology and Agric.
Extension)\} is a specialist in Animal genetics and breeding. He was the formal Ag.
Dean, Faculty of Agriculture Education of University of Education Winneba, and a
member of the University council. Helectures in Principle of Animal Genetics and
Breeding, Biometry, Agricultural Biotechnology, and Animal Production and
Management.

